\title{
E-Journals Usage Trend in IUB Library
}

\author{
Muhammad Hossam Haider Chowdhury ${ }^{1}$
}

\begin{abstract}
This article aims to give a general understanding about the popularity of electronic resources in Independent University, Bangladesh, which would help in shaping higher education in the country. Resources usages were determined on the basis of electronic resources providers' data. The article comes up with some important findings. Use of Emerald database in IUB found to be more rational compared to other three IP based databases. The ratios between the top-most and the $25^{\text {th }}$ documents those opened, from Emerald 5:1, from JSTOR 13:1, from ABI/Inform 19:1, from OUP Journals 31:1. Users preferred PDF documents and Period had no influence over usage. The study only covered IP based electronic resources; password based or other free electronic resources were out of the study. This is the first case study on the use of electronic resources in Bangladesh, which would give Bangladeshi libraries a guidance regarding electronic resources subscription.
\end{abstract}

Keywords: E-Journal, Usage statistics, IUB, Bangladesh

\section{Introduction}

In the age of Internet and electronic resources, especially e-journals are important learning materials those are playing certainly a significant role in the library services. Digital resources provide many opportunities and challenges for libraries (Sharma and Vishwanathan, 2001; Frumkin, 2004; Liu, 2004; Kettunen, 2007). Use of Internet is increasing day by day and libraries are playing a vital role to make considerable use of Internet's numerous facilities by the researchers and students (Hollis, 1998). To-day's libraries are turning into 'access point libraries' from big warehouse type of libraries. Electronic publications are rapidly developing and changing the environment of learning (Svenningsen, 1998). In higher education electronic resources become part and parcel of the academic process (Mutula and Makando, 2003). Researchers cannot think of performing their work without adequate access to electronic resources. Many resources are available free of cost. Even if one cannot subscribe, s/he can have at least some resources from the internet without any charge from the publishers. Free resources initially fill up the need of information seekers. But higher education and research need strong base of information which is usually ensured through libraries by subscribing to

\footnotetext{
Librarian, Independent University, Bangladesh (IUB), Baridhara, Dhaka 1212, Emial:mhhc@iub.edu.bd
} 


\section{Bangladesh Journal of Library and Information Science}

full text databases and obviously facilitating browsing. Hollis emphasized on high performance networking for the Internet use in the academic libraries (1998). He described that Internet connection as must for all academic libraries. Electronic journals are now found cost-effective being it ensures the multiple user access at a time and eventually the price becomes acceptable to the institutions (Rowley, 2000).

\section{Purpose of the Study}

Subscription to electronic resources is a new phenomenon in library activities of Bangladesh. Confusion exists about the e-journal subscription in our country. Whether these resources are useful or just prestige symbol of the respective institutes needs to be resolved. This study is a step for eliminating confusion focusing on the usage of electronic resources in Independent University, Bangladesh (IUB). This report is basically concerned with the use of resources in IUB to find out the status of the use of electronic resources and the types of resources that are in great demand. The study may help the decision makers of the universities and higher education institutions to gauge the use and popularity of e-resources in educational environment of Bangladesh.

\section{Study Plan and Limitation}

This study is based on information received from the usage statistics of full text electronic resources providers of IUB Library. All four e-resources providers used COUNTER for statistics. It should be need that a group of publishers and librarians worked together under the umbrella of Project COUNTER to develop an internationally accepted Code of Practice that enables vendors to provide trust worthy statistics (Davis and Solla, 2003). Resources that were active in IUB in 2007 and could be reached through the university's proxy server's IP address have been taken into consideration. This focused on most-used e-journals; the format of documents that users preferred and the peak months of usage. Observing the use pattern the study tried to comprehend the position of the electronic resources in the university library.

\section{Electronic Resources Use in Bangladesh}

Bangladesh has recently been experiencing the use of electronic resources. At present libraries of Independent University, Bangladesh (IUB), Dhaka University, Jahangirnagar University, Rajshahi University, Chittagong University, North South University, East West University, BRAC University (BU), South East University, Bangladesh Council of Scientific and Industrial Research, Bangladesh Atomic Energy Commission are subscribing to electronic resources. Probably BU showed the courage first to go for pay electronic journals by subscribing Jstor in 2002. Recently the North South University is also claiming that they also started subscription to Jstor in 2002. However, the next year IUB also started to get access to Jstor through subscription. Until 2006 when International Network for Avialability of Scientific Publications (INASP) opened a chapter for Bangladesh through Programme for the Enhancement of Research Information (PERI) with a view to develop a consortium for electronic resources subscription, except IUB, no other library subscribe to other electronic databases. There were some initiatives for forming consortia for acquiring electronic journals. UGC has been trying to figure out a consortium for the university libraries of Bangladesh since 2005 (Nazimuddin and Chowdhury, 2006). In the meantime Bangladesh Academy of Science successfully implemented PERI consortium. 


\section{Strength of IUB Library}

The IUB Library generally serves around 3,000 students mostly undergraduate and 190 faculty members. Moreover, 203 officers and staff, 109 Trust and donor members as well as the alumni can also approach for library services. Students and faculty members are spread out in four schools - School of Business, School of Engineering and Computer Science, School of Environmental Science and Management and School of Liberal Arts and Social Sciences. The University launched its library from its inception, i.e., 1993. The IUB Library in Dhaka holds over twenty five thousands volumes which include books, back issues journals, cassettes and CD-ROMs. Currently the library has subscription to 90 print titles.

So far the electronic resources are concerned, IUB advanced a step forward compared to its peers when it started subscribing to Emerald Full Text in 2004. In 2006, IUB had a trial for INASP resources from May to December, and for ScienceDirect from August to October and in 2007 for ABI/Inform during February/March. Due to the popularity of electronic resources for business affairs IUB extended full text journals subscription in 2007 by subscribing to ABI/Inform Global from ProQuest. Besides IUB has been successfully utilizing the free resources available on the Internet, especially for the developing countries that includes Oxford University Press (OUP) Journals, Health InterNetwork Access to Research Initiative (HINARI), Access to Global Online Research in Agriculture (AGORA), Online Access to Resources in the Environment (OARE), etc. Users in IUB can access the resources of HINARI, AGORA, OARE and others through password instead of IP. However, IUB recently joined the consortium coordinated by the Academy of Sciences.

\section{Usage of Oxford University Press Journals in IUB}

IUB received permission to access OUP journals for developing countries in September 2003. Agreement between OUP and IUB ensures free access to over 150 titles. This is the first brand 'bundle' ${ }^{3}$ of electronic resources that were made available for the IUB library users. But it was not found very popular. Through September to December in 2003 only 5 articles were read/downloaded from two titles - four documents from the Enterprise \& Society: The International Journal of Business History and the other one from The Year's Work in English Studies. Following year the use of OUP journals increased, even than it was very poor. Only 82 articles were viewed from 16 titles. ELT Journal was ranked number one being 35 documents read from this, then The Review of Financial Studies, Journal of Experimental Botany, Behavioral Ecology and Nucleic Acids Research were ranked $2^{\text {nd }}, 3^{\text {rd }}$, $4^{\text {th }}$ and $5^{\text {th }}$ respectively. In 2005 total 312 full text documents were viewed/downloaded - 285 in PDF and 27 in HTML - from 20 titles. The ELT journal again was the highest used journal. One hundred ninety five documents were viewed/downloaded only from this journal in 2005. $2^{\text {nd }}$ highest is Health Promotion International from which 22 articles were downloaded only. Oxford Economic Papers, The World Bank Economic Review and The World Bank Research Observer were in $3^{\text {rd }}, 4^{\text {th }}$ and $5^{\text {th }}$ positions respectively. The month September was in the peak for 92 documents and October was the second for 62 documents viewed in 2005.

In 2006, maximum documents were viewed from OUP Journals. Total viewed documents found 460 of which 391 PDF and 69 HTML from 67 titles. This year highest numbers of titles were consulted from this database. ELT Journal again hit highest which is 69, Health Policy and Planning was second for 43 articles. Family Practice, Occupational Medicine and The World Bank Economic Review were positioned $3^{\text {rd }}$, $4^{\text {th }}$ and $5^{\text {th }}$ respectively. In November 32 and in May 


\section{Bangladesh Journal of Library and Information Science}

20 documents were downloaded and they placed top two periods of usage in this year. In 2007 up to August, only 69 titles were consulted by the IUB Library users and downloaded 337 articles of which 218 in PDF format and 119 in HTML format. By downloading 30 articles from Health Policy and Planning it ranked number one and second is the International Journal of Epidemiology from where 29 full text were read/downloaded in this year. Health Promotion International, ELT Journal and American Journal of Epidemiology were placed $3^{\text {rd }}$, $4^{\text {th }}$ and $5^{\text {th }}$ in usage ranking. By opening 66 documents in March and another 55 in April, these two months were found as two peak periods of usage.

Table-1 : Titles from Oxford University Press Journals used maximum in IUB.

\begin{tabular}{|c|c|c|c|}
\hline \multicolumn{4}{|l|}{ Most Preferred 25 OUP journals in IUB } \\
\hline Titles & Total & PDF & HTML \\
\hline ELT Journal & 322 & 297 & 25 \\
\hline Health Policy and Planning & 77 & 71 & 6 \\
\hline International Journal of Epidemiology & 60 & 35 & 25 \\
\hline Health Promotion International & 51 & 25 & 26 \\
\hline The World Bank Economic Review & 42 & 42 & 0 \\
\hline Family Practice & 42 & 39 & 3 \\
\hline Oxford Economic Papers & 36 & 26 & 10 \\
\hline Occupational Medicine & 32 & 32 & 0 \\
\hline Applied Linguistics & 28 & 22 & 6 \\
\hline American Journal of Epidemiology & 25 & 8 & 17 \\
\hline The Review of Financial Studies & 24 & 22 & 2 \\
\hline The World Bank Research Observer & 23 & 23 & 0 \\
\hline The European Journal of Public Health & 18 & 18 & 0 \\
\hline The British Journal of Social Work & 18 & 18 & 0 \\
\hline Enterprise \& Society: The International Journal of Business History & 16 & 11 & 5 \\
\hline Journal of Tropical Pediatrics & 16 & 16 & 0 \\
\hline Social History of Medicine & 14 & 14 & 0 \\
\hline BJA: British Journal of Anaesthesia & 13 & 12 & 1 \\
\hline Health Education Research & 13 & 8 & 5 \\
\hline The Computer Journal & 13 & 13 & 0 \\
\hline Epidemiologic Reviews & 12 & 6 & 6 \\
\hline QJM: An International Journal of Medicine & 12 & 8 & 4 \\
\hline Oxford Review of Economic Policy & 11 & 11 & 0 \\
\hline Journal of Experimental Botany & 11 & 8 & 3 \\
\hline Mathematical Medicine and Biology: A Journal of the IMA & 11 & 11 & 0 \\
\hline
\end{tabular}


One hundred one titles from OUP journals somehow consulted from the university sites since 2003. Up to 2006 there was an upward trend of usage of the resources. Table 1 shows the aggregated use of OUP journals since 2003 in IUB. Users preferred format of document was PDF. This full text database was found comparatively useful for English language, Health and Medicine. Period was not set up as a significant factor for choosing OUP Journal database.

\section{Usage of JSTOR}

JSTOR is the first subscribed full text database of IUB. Subscription was started at the end of 2003. Initially subscription was gone for Art and Science I and Business sections of the JSTOR and 115 titles were available for IUB. Immediately after the subscription it became popular. Only in February 2004 downloading was 820 full texts and in March it was 499. Total 1,981 full texts documents were downloaded in this year. PDF documents were 1,698 and 279 were in HTML format. Six hundred sixty one articles were downloaded only from the Journal of Finance, 216 were read from the American Economic Review, 202 from the Journal of Financial and Quantitative Analysis, 137 from the Journal of Business and 108 from the Journal of Political Economy. Fifty or higher number of documents were downloaded only from 8 titles in 2004. Total 61 titles were consulted from JSTOR in 2004.

In May 2005 subscription was gone for all sections of JSTOR. Among 584 titles available in JSTOR, our users consulted only 186 titles in 2005. One hundred twenty articles were downloaded from the Accounting Review, 114 form the Journal of Marketing, 93 from the Journal of Finance, 86 from the Strategic Management Journal, 60 from the Modern Language Journal. All other titles were consulted for less than 50 documents each. Total 1,689 documents were read/downloaded in this period - 1,047 were in PDF and others in HTML. Three hundred ninety eight titles were not even looked into. August and September were the two topmost usage months as 266 and 254 documents were downloaded respectively.

Of 673 titles IUB library users consulted with 408 titles in 2006. Four hundred thirty two documents were consulted from the Journal of Marketing, 328 from Journal of Finance, 258 from the Management Science and same number from the Academy of Management Journal, 211 from the Journal of Marketing Research. More than 50 documents were downloaded from 25 titles each. Two hundred sixty five titles were not opened by our users in this year. Total 6,108 documents of which 3,191 were in PDF and 2,904 were in HTML were downloaded in 2006. In November 1,359 and in April 1,330 documents were downloaded.

Table-2 : Most used 25 titles of JSTOR from 2004 to 2007.

\begin{tabular}{|l|c|c|c|}
\hline Most Preferred 25 titles of JSTOR in IUB & \multicolumn{3}{c|}{} \\
\hline Titles & Total & PDF & HTML \\
\hline Journal of Finance & 1923 & 1389 & 532 \\
\hline Journal of Marketing & 992 & 523 & 465 \\
\hline American Economic Review & 591 & 402 & 189 \\
\hline Journal of Financial and Quantitative Analysis & 556 & 402 & 154 \\
\hline Accounting Review & 488 & 235 & 250 \\
\hline
\end{tabular}




\section{Bangladesh Journal of Library and Information Science}

\begin{tabular}{|l|c|c|c|}
\hline Titles & Total & PDF & HTML \\
\hline Academy of Management Journal & 458 & 209 & 248 \\
\hline Journal of Marketing Research & 442 & 235 & 207 \\
\hline Management Science & 407 & 138 & 269 \\
\hline Journal of Business & 341 & 265 & 76 \\
\hline Academy of Management Review & 338 & 169 & 169 \\
\hline Journal of Consumer Research & 288 & 184 & 103 \\
\hline Journal of Money, Credit and Banking & 284 & 178 & 106 \\
\hline Strategic Management Journal & 265 & 117 & 148 \\
\hline Journal of Political Economy & 240 & 166 & 74 \\
\hline Journal of Risk and Insurance & 223 & 172 & 51 \\
\hline Theatre Journal & 190 & 176 & 14 \\
\hline Quarterly Journal of Economics & 171 & 101 & 70 \\
\hline Review of Economics and Statistics & 166 & 97 & 69 \\
\hline Journal of International Business Studies & 165 & 76 & 89 \\
\hline Journal of Accounting Research & 165 & 78 & 87 \\
\hline Asian Survey & 165 & 60 & 105 \\
\hline Journal of Organizational Behavior & 165 & 100 & 63 \\
\hline Studies in Family Planning & 159 & 78 & 80 \\
\hline MIS Quarterly & 157 & 61 & 94 \\
\hline Review of Financial Studies & 118 & 34 \\
\hline
\end{tabular}

Of 733 titles only 494 titles were read/downloaded and 239 titles were completely untouched in 2007. This year, the Journal of Finance was consulted maximum and 1054 documents were viewed full text from this title. From the Journal of Marketing 549, from the American Economic Review 325, from the Journal of Financial and Quantitative Analysis 292 and from the Journal of Money, Credit and Banking 288 documents were downloaded. Fifty or more documents were downloaded from 49 titles each in 2007. Out of these 49 titles from 24 titles 100 or more documents were downloaded this year. Of total 11,407 full text documents 5,516 were in PDF and 5,857 were in HTML. Two thousand Five hundred seventy documents were consulted only in August and 1,630 in April.

As shown in Table 2 among 25 JSTOR titles viewed most since 2004 except 3 titles all other somehow related to business. There were some use for art, social science and health. Users, here also, preferred PDF files for their reading. JSTOR titles were getting popularity gradually. There was seen an increasing trend of variation of the titles consultation. Months with initial 'A' found busy period as both April and August placed twice each at top two usage months of the years. 


\section{Usage of ProQuest (ABI/Inform)}

IUB Library has subscription to ABI/Inform - one database of ProQuest. ProQuest's Dissertations and Theses is the highest used title of which 375 full text articles in PDF format were downloaded in 2007. Journal of Business Ethics is the second highest used journal. From this title 170 documents were opened in PDF format and 1 in HTML format. Journal of American Academy of Business, Cambridge was the third. One hundred forty one articles were opened or downloaded from it. Financial Times and The Business Review, Cambridge were $4^{\text {th }}$ and $5^{\text {th }}$ position in respect of usage. Though there were rights to access over 2,000 titles from ABI/Inform of ProQuest only 745 titles were consulted by the IUB users and total 3,949 documents were either read or downloaded. Except topmost six titles all others were consulted for less than 50 documents each. July is the month when maximum numbers of articles were downloaded. This time 1,262 documents were opened. By opening 778 documents in March it placed second highest period of usage.

Table 3 : Top 25 Journals used from ABI/Inform of ProQuest

\begin{tabular}{|l|c|c|c|}
\hline Preferred 25 titles of ABI/Inform in IUB & Total & PDF & HTML \\
\hline Titles & 407 & 407 & 0 \\
\hline E ProQuest Dissertations and Theses & 171 & 170 & 1 \\
\hline Journal of Business Ethics & 141 & 113 & 28 \\
\hline Journal of American Academy of Business, Cambridge & 63 & 0 & 63 \\
\hline Financial Times & 56 & 0 & 56 \\
\hline Wall Street Journal & 56 & 50 & 6 \\
\hline The Business Review, Cambridge & 46 & 41 & 5 \\
\hline Canadian HR Reporter & 45 & 39 & 6 \\
\hline HRMagazine & 44 & 38 & 6 \\
\hline Personnel Today & 39 & 38 & 1 \\
\hline Organization Development Journal & 38 & 37 & 1 \\
\hline Leadership \& Organization Development Journal & 37 & 35 & 2 \\
\hline Strategy \& Leadership & 36 & 35 & 1 \\
\hline Journal of Leadership \& Organizational Studies & 33 & 33 & 0 \\
\hline Strategic Finance & 32 & 29 & 3 \\
\hline Workforce & 32 & 0 & 32 \\
\hline EIU ViewsWire & 30 & 28 & 2 \\
\hline Business and Society & 29 & 26 & 3 \\
\hline HR Focus & 26 & 0 & 26 \\
\hline Knight Ridder Tribune Business News & 26 & 26 & 0 \\
\hline Physician Executive & 25 & 23 & 2 \\
\hline Strategic Communication Management & & \\
\hline
\end{tabular}




\section{Bangladesh Journal of Library and Information Science}

\begin{tabular}{|l|c|c|c|}
\hline Titles & Total & PDF & HTML \\
\hline The International Journal of Bank Marketing & 24 & 17 & 7 \\
\hline Quality Progress & 23 & 21 & 2 \\
\hline Personnel Psychology & 22 & 20 & 2 \\
\hline American Bankers Association. ABA Banking Journal & 21 & 19 & 2 \\
\hline
\end{tabular}

Mostly business oriented titles were consulted from this database. Table 3 contains all business related titles. Though ABI/Inform basically was a business database, it included many social science and computer related titles. Users again preferred PDF documents for their reading. $\mathrm{ABI} /$ Inform was in the first year of use in IUB and duly comparing period factors were absent.

\section{Usage of Emerald}

In 2006 out of 220 titles 177 titles were read from IUB site and 35,418 full text documents were either opened or downloaded. Top most five used journals were:

International Journal of Bank Marketing — 2218 full text opened

European Journal of Marketing - 1879 full text opened

New Library World - 1670 full text opened

Journal of Services Marketing - 1355 full text opened

Journal of Product \& Brand Management - 1258 full text opened

Twenty two titles hit over 500 times each for full texts in 2006. vis-à-vis 37 titles were not even opened.

In 2007 out of 221 titles 174 titles were consulted for full text. 17,730 documents were downloaded only in July 2007 and 10,766 articles were in April 2007. Total 64,646 documents were consulted or opened in this year. Five top used titles were:

International Journal of Bank Marketing - 4,260 full text opened

European Journal of Marketing - 2,680 full text opened

Library Management - 2,119 full text opened

Journal of Product \& Brand Management - 1,935 full text opened

International Journal of Service Industry Management - 1,848 full text opened

Table 4 : Top 25 Journals used from Emerald Full Text

\begin{tabular}{|l|c|c|c|}
\hline Preferred 25 Emerald titles in IUB & Total & PDF & HTML \\
\hline Titles & 6478 & 5145 & 1333 \\
\hline International Journal of Bank Marketing & 4559 & 3755 & 804 \\
\hline European Journal of Marketing & 3193 & 2540 & 653 \\
\hline Journal of Product \& Brand Management & 3177 & 2546 & 631 \\
\hline Journal of Services Marketing & &
\end{tabular}


Bangladesh Journal of Library and Information Science

\begin{tabular}{|l|c|c|c|}
\hline Titles & Total & PDF & HTML \\
\hline International Journal of Service Industry Management & 2964 & 2361 & 603 \\
\hline Managing Service Quality & 2745 & 2154 & 591 \\
\hline International Journal of Retail \& Distribution Management & 2654 & 2003 & 651 \\
\hline Library Management & 2460 & 1050 & 1410 \\
\hline Journal of Consumer Marketing & 2409 & 1925 & 484 \\
\hline Leadership \& Organization Development Journal & 2407 & 2023 & 384 \\
\hline Management Decision & 2387 & 2004 & 383 \\
\hline Marketing Intelligence \& Planning & 2217 & 1810 & 407 \\
\hline Managerial Auditing Journal & 2077 & 1775 & 302 \\
\hline Journal of Business \& Industrial Marketing & 1903 & 1635 & 268 \\
\hline New Library World & 1825 & 643 & 1182 \\
\hline Journal of Managerial Psychology & 1784 & 1462 & 322 \\
\hline Personnel Review & 1736 & 1345 & 391 \\
\hline Journal of Management Development & 1706 & 1427 & 279 \\
\hline International Journal of Social Economics & 1626 & 1295 & 331 \\
\hline Library Hi Tech & 1530 & 661 & 869 \\
\hline International Journal of Manpower & 1505 & 1133 & 372 \\
\hline International Journal of Quality \& Reliability Management & 1378 & 1120 & 258 \\
\hline Industrial Management \& Data Systems & 1333 & 1112 & 221 \\
\hline Journal of European Industrial Training & 1327 & 1104 & 223 \\
\hline International Journal of Operations \& Production Management & 1318 & 1115 & 203 \\
\hline
\end{tabular}

Eighteen journals hit over 1,000 each for the full texts and 24 more journals had over 500 hits each for full texts. Another 56 (98-42) journals hit over 100 each. Fifty plus hits had 24 (12298) more titles.

International Journal of Service Industry Management was placed $5^{\text {th }}$ in the aggregated ranking though it was absent in separate yearly ranking of five top titles. Top $12^{\text {th }}$ in Emerald has higher usage figure than the topmost used journal of JSTOR. Though Emerald's figure is for two years, i.e., 2006 and 2007, whereas JSTOR's figures calculated since 2004. Total 184 titles were consulted in two years from 221 titles available in the Emerald for IUB.

Report of Emerald for 2005 per journal was not available at administrative login. Only current and previous years reports for per journal per month could get from administrative login. Summary report per month for 2005 only be retrieved, but not per journal information. As per summary report 12, 340 full text documents were viewed throughout the year 2005. Information of 2004 was totally absent. Table 4 includes only combined usage figures of 2006 and 2007. 


\section{Bangladesh Journal of Library and Information Science}

\section{Discussion}

Emerald full text database was found most popular in IUB Library. Emerald deals mainly with management. Most of the students of IUB prefer to study business courses and that would be the main reason for its popularity in this university. Of most used ten Emerald journals, nine were on business. Except three journals all others in top 25 titles were directly or indirectly on business related. Same to JSTOR, i.e. only three titles are not related to business in maximum consulted 25 titles. In ABI/Inform only one title was out of business affairs. Exception found in OUP Journals where only five titles in top used 25 titles were on business. Quite a good number of titles were related to Health and Medicine in OUP Journals' top 25 titles used.

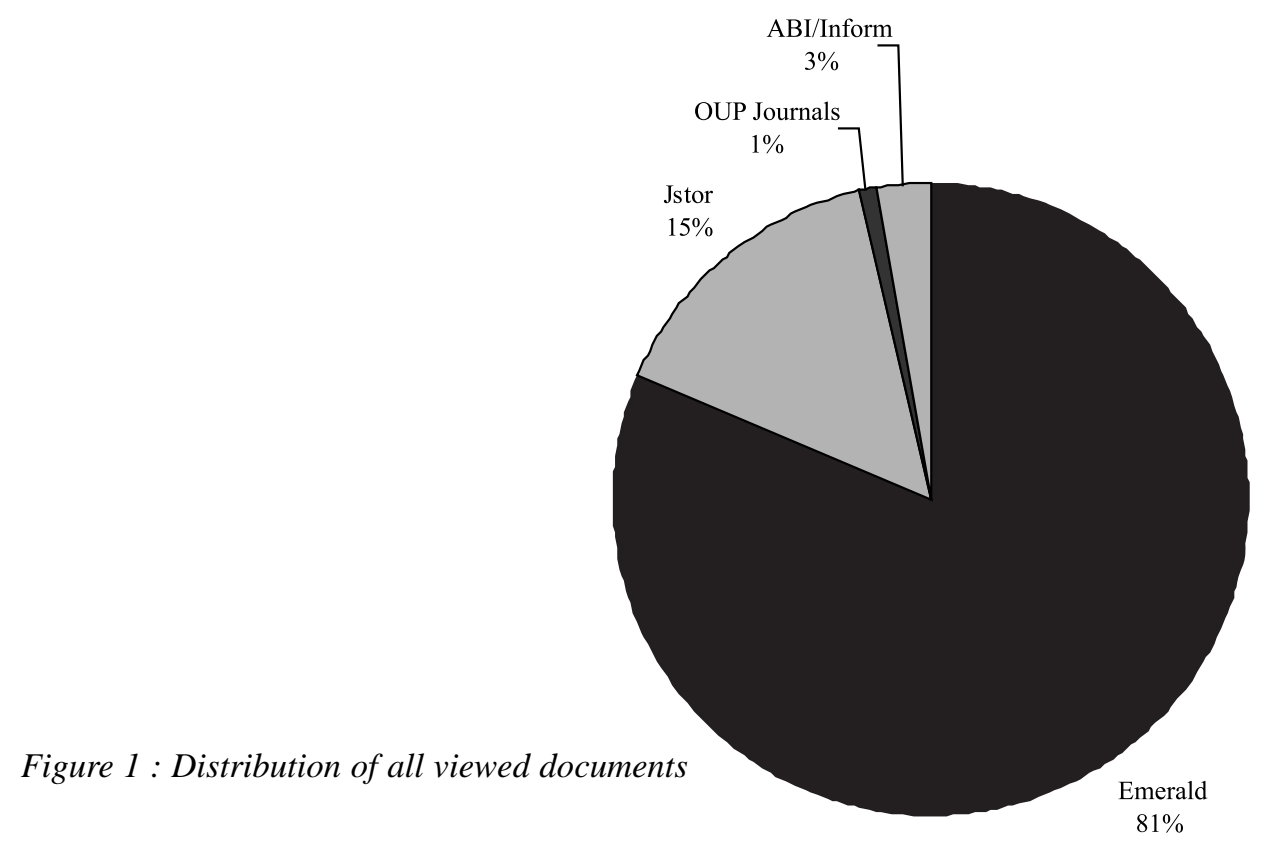

Faculty members of the School of Business played an important role to link the electronic resources with their courses and that made the resources more usable. In all cases users preferred PDF files to read. The usage of Emerald titles is much more higher than any other full text databases available in IUB. Table - 5 shows that from Emerald 1,12,404 documents were viewed in IUB and second highest position that placed by JSTOR was viewed less than one fifth being 21,185 document were read from the university sites. OUP journals placed last even though it was available since 2003. Only 1\% documents were viewed from OUP journals (Figure 1).

ProQuest's ABI/Inform was launched in February 2007 but users started to look into this database seriously from March. In this respect the number of usage is not bad. Figure -2 shows that maximum titles were consulted from ABI/Inform of ProQuest. It was reported that many users preferred Emerald over ABI/Inform due to the documents format. ABI/Inform gives image format in PDF files. Due to image format it took longer time to download. In fact in management view this, images, would less efficient as this eat up the bandwidth of the university. 
Bangladesh Journal of Library and Information Science

Table 5 : Total Documents Downloaded from Different Platforms

\begin{tabular}{|l|c|c|c|c|c|}
\hline Platforms & $\mathbf{2 0 0 4}$ & $\mathbf{2 0 0 5}$ & $\mathbf{2 0 0 6}$ & $\mathbf{2 0 0 7}$ & Total \\
\hline $\begin{array}{l}\text { Emerald } \\
\text { Insight }\end{array}$ & $\begin{array}{c}\text { Information } \\
\text { not available }\end{array}$ & 12,340 & 35,418 & 64,646 & 112,404 \\
\hline JSTOR & 1,981 & 1,689 & 6,108 & 11,407 & 21,185 \\
\hline OUP Journals & 92 & 312 & 460 & 337 & 1201 \\
\hline ProQuest & $\begin{array}{c}\text { Subscription } \\
\text { not started }\end{array}$ & Subscription & Subscription & 3,949 & 3,949 \\
\hline Grand Total & $\mathbf{2 , 0 7 3}$ & $\mathbf{1 4 , 3 4 1}$ & $\mathbf{4 1 , 9 8 6}$ & $\mathbf{8 2 , 3 4 6}$ & $\mathbf{1 3 8 , 7 3 9}$ \\
\hline
\end{tabular}

Use of Emerald database in IUB found more rational comparing to other three databases. The ratio of the topmost and the $25^{\text {th }}$ documents those opened in two years from Emerald was 5:1. JSTOR's titles ratio for the same for four years was 13:1. ProQuest has strong prospect to receive users' attention being its ratio for same in only a year placed 19:1. OUP Journal titles not only received less attention in number but also had high gap between the topmost and the $25^{\text {th }}$ titles, i.e., 29:1. But gradually use of OUP journals had also been increasing.

In no case period was the factor of use. It varies year to year or platform to platform. No connection was found between usage and the months of usage. December/January and May/June, i.e., in the off semesters, usage was found extremely few comparing to other months. That means that usage depends on class works given to students.

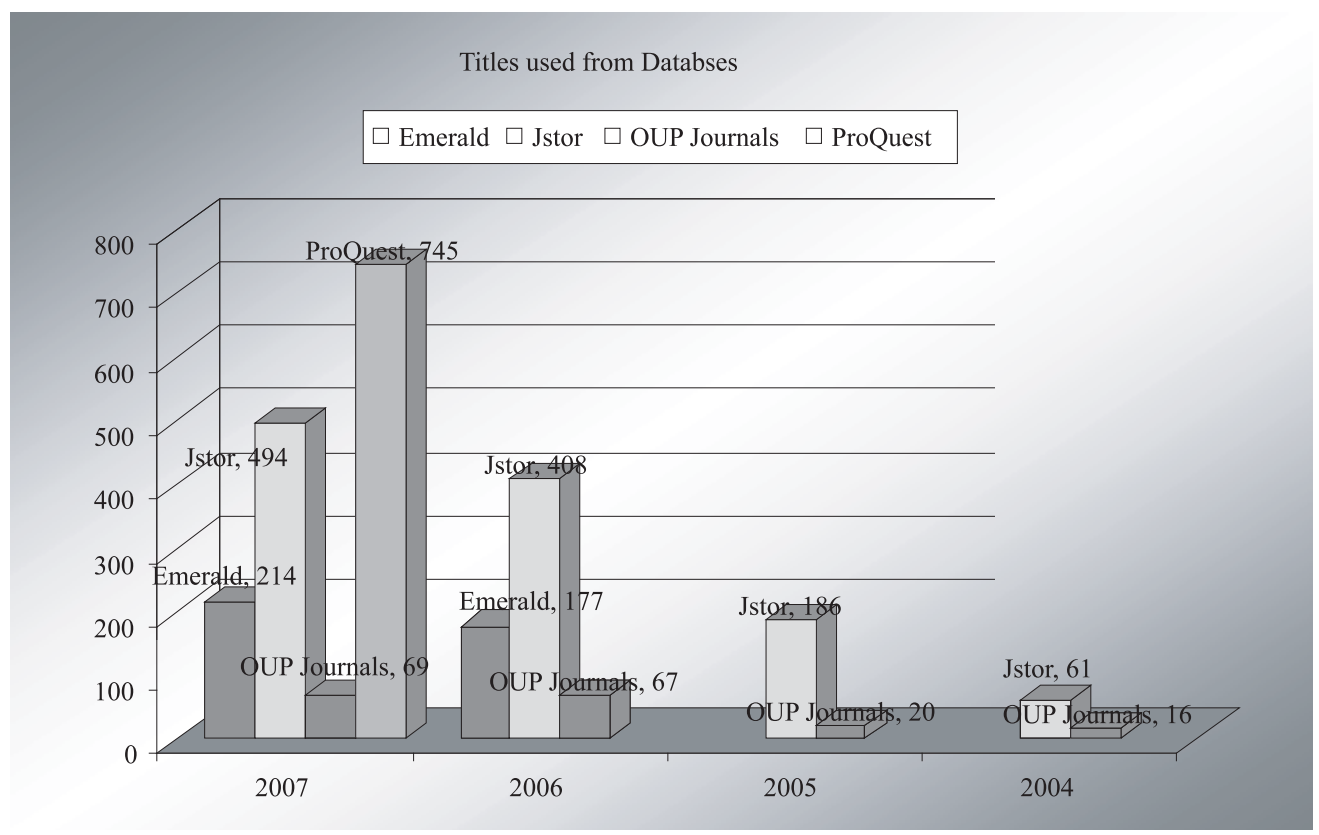

Figure - 2 : Titles used from different platforms 


\section{Bangladesh Journal of Library and Information Science}

Phil Davis found little similarity in the uses of e-journals at undergraduate institutions (2002). Many other studies also validated Davis's findings which would be of value to collection development (Medeiros, 2005). But IUB's data differs little bit with those findings.

Except few hundred students all other students were studying at the undergraduate level in IUB. Visitors of the IUB Library were found mostly undergraduate students. All the library computers were used to keep busy by those students. It was also reported that library took the larger share of the university bandwidth. So, apparently we understood undergraduate students were the main users and the Emerald and ProQuest were heavily used by the undergraduate students of the School of Business. As JSTOR's used titles were again mostly on business affairs it is also indicating that undergraduate students made this number. In JSTOR the Journal of Finance is common in top five used titles of every year. Journal of Marketing only absent in one year's top five hit list. Three other titles - American Economic Review, Journal of Financial and Quantitative Analysis and Accounting Review - are also found common in half of the scheduled years of JSTOR for this purpose. In Emerald database International Journal of Bank Marketing and European Journal of Marketing both were $1^{\text {st }}$ and $2^{\text {nd }}$ respectively in both the years. Journal of Product \& Brand Management is also common in top most used five titles of Emerald. May be these were common due to little options were available for choosing different other titles from IUB or due to generalization on the basis of apparent library use, not through on strict log in data.

\section{Conclusion}

Remotely accessible resources are helping libraries for growing with contents without extending its physical structures. It is now dominating world wide libraries. Electronic resources are getting importance to even small academic and public libraries and they are consuming larger share of library budgets in many cases (White, 1997). This trend cannot be ignored in our country. On the other hand, physical growth of libraries in Bangladesh in most cases is very slow. Electronic resources can play vital role to expand libraries' resources. It will be practical in to-days environment for any library to move gradually into access point library concept for the journal acquisition. The Experience of IUB Library indicates that the relevant materials have incredible use if those can be made available for the users of Bangladesh, though in case of IUB most of the users were interested on business. It needs to be examined that why other schools' users were not have interest to consult the e-resources available in IUB. Bangladesh Academy of Science has done a great job by opening a chapter for Bangladesh in PERI of INASP. If more libraries participated with the PERI than subscription for each library will come down being Academy is paying for whole Bangladesh. Subsequently, other consortia may be formed for exploring more electronic resources at an affordable price and higher education libraries, at least, will then find more users. Users will take interest for research and ultimately the country will get immense benefit.

\section{References}

Davis, P.M. (2002), Patterns of electronic journal usage: challenging the composition of geographic consortia, College \& Research Libraries, Vol. 63 No. 6, pp. 484-97.

Davis, P.M. and Solla, L. R. (2003), An IP-level analysis of usage statistics for electronic journals in chemistry : making inferences about user behavior, Journal of the American Society 
for Information Science and Technology, Vol.54, No. 11, pp.1062-68

Frumkin, J. (2004), The problem of mainstreaming digital libraries, OCLC Systems \& Services, Vol. 20 No. 3, pp. 106-9.

Hollis, Ann (1998). The Internet and acquisitions in academic libraries. In: Library Review, Vol. 47 No. 1, pp. 26-30

Kettunen, Juha.( 2007). The strategic evaluation of academic libraries. Library Hi Tech Vol. 25 No. 3, pp. 409-421

Liu, Y.Q. (2004), Is the education on digital libraries adequate? New Library World, Vol. 105 Nos 1/2, pp. 60-8.

Medeiros , Norm (2005). "Electronic resource usage statistics: the challenge and the promise", OCLC Systems \& Services, Vol. 21 No. 3, pp. 145-147

Mutula, S.M. and Makando, F.S. (2003). "IT skill needs for collection development process at the University of Botswana library”, Library Hi Tech, Vol 21, No. 1, p.94-101

Nazimuddin, M. and Chowdhury, M.H.H. (2006). "Developing a digital resources consortium for university libraries in Bangladesh : proposed role of UGC", in Digital Libraries : achievements, challenges and opportunities : $9^{\text {th }}$ International Conference on Asian Digital Libraries, ICADL, 2006, Kyoto, Japan, Proceedings, Springer, pp.490-3

Rowley, Jennifer (2000). “The question of electronic journals”, Library Hi Tech, Vol 18, No 1. pp. 46-54

Sharma, R.K. and Vishwanathan, K.R. (2001), "Digital libraries: development and challenges”, Library Review, Vol. 50 No. 1, pp. 10-16.

Svenningsen , Karen (1998). "An evaluation model for electronic resources utilizing cost analysis”, The Bottom Line: Managing Library Finances Vol 11, No. 1, pp. 18-23

White, Gary W. and Crawford, Gregory A. (1997). "Developing an electronic information resources collection development policy”, Asian Libraries, Vol. 6 No. 1/2, pp. 51-56. 